Article

\title{
One Pot Selective Arylation of 2-Bromo-5-Chloro Thiophene; Molecular Structure Investigation via Density Functional Theory (DFT), X-ray Analysis, and Their Biological Activities
}

\author{
Nasir Rasool ${ }^{1, *}$, Aqsa Kanwal ${ }^{1}$, Tehmina Rasheed ${ }^{1}$, Quratulain Ain ${ }^{1}$, Tariq Mahmood ${ }^{2}$, \\ Khurshid Ayub ${ }^{2}$, Muhammad Zubair ${ }^{1}$, Khalid Mohammed Khan ${ }^{3}$, \\ Muhammad Nadeem Arshad ${ }^{4,5}$, Abdullah M. Asiri ${ }^{4,5}$, Muhammad Zia-Ul-Haq ${ }^{6}$ \\ and Hawa Z. E. Jaafar ${ }^{7, *}$ \\ 1 Department of Chemistry, Government College University Faisalabad, Faisalabad 38000, Pakistan; \\ aqsakanwal.chem@yahoo.com (A.K.); tehmina.rasheed1@gmail.com (T.R.); \\ quratulainayyub@yahoo.com (Q.A.); nr_308@hotmail.com (M.Z.) \\ 2 Department of Chemistry, COMSATS Institute of Information Technology, University Road, Tobe Camp, \\ Abbottabad 22060, Pakistan; mahmood@ciit.net.pk (T.M.); khurshid@ciit.net.pk (K.A.) \\ 3 H.E.J. Research Institute of Chemistry, International Center for Chemical and Biological Sciences, \\ University of Karachi, Karachi 75270, Pakistan; khalid.khan@iccs.edu \\ 4 Departments of Chemistry, Faculty of Science, King Abdulaziz University, Jeddah 21589, Saudi Arabia; \\ mnachemist@hotmail.com (M.N.A.); aasiri2@kau.edu.sa (A.M.A.) \\ 5 Center of Excellence for Advanced Materials Research (CEAMR), Faculty of Science, \\ King Abdulaziz University, Jeddah 21589, Saudi Arabia \\ 6 The Patent Office, Karachi 75270, Pakistan; ahirzia@gmail.com \\ 7 Department of Crop Science, Faculty of Agriculture, 43400 UPM Serdang, Selangor, Malaysia \\ * Correspondence: nasirrasool@gcuf.edu.pk (N.R.); hawazej@gmail.com (H.Z.E.J.); \\ Tel.: +92-332-7491790 (N.R.); +60-3-894-74821 (H.Z.E.J.); \\ Fax: +92-41-9201032 (N.R.); +60-3-8946-4107 (H.Z.E.J.)
}

Academic Editor: Abihijit Chatterjee

Received: 7 April 2016; Accepted: 13 May 2016; Published: 28 June 2016

\begin{abstract}
Synthesis of 2,5-bisarylthiophenes was accomplished by sequential Suzuki cross coupling reaction of 2-bromo-5-chloro thiophenes. Density functional theory (DFT) studies were carried out at the B3LYP/6-31G $(d, p)$ level of theory to compare the geometric parameters of 2,5-bisarylthiophenes with those from $X$-ray diffraction results. The synthesized compounds are screened for in vitro bacteria scavenging abilities. At the concentration of 50 and $100 \mu \mathrm{g} / \mathrm{mL}$, compounds $\mathbf{2 b}, \mathbf{2 c}, \mathbf{2 d}, \mathbf{3 c}$, and $\mathbf{3} \mathbf{f}$ with $\mathrm{IC}_{50}$-values of $51.4,52.10,58.0,56.2$, and $56.5 \mu \mathrm{g} / \mathrm{mL}$ respectively, were found most potent against E. coli. Among all the synthesized compounds $\mathbf{2 a}, \mathbf{2 d}, \mathbf{3 c}$, and $3 \mathbf{e}$ with the least values of $\mathrm{IC}_{50}$ 77, 76.26, $79.13 \mu \mathrm{g} / \mathrm{mL}$ respectively showed significant antioxidant activities. Almost all of the compounds showed good antibacterial activity against Escherichia coli, whereas 2-chloro-5-(4-methoxyphenyl) thiophene (2b) was found most active among all synthesized compound with an $\mathrm{IC}_{50}$ value of $51.4 \mu \mathrm{g} / \mathrm{mL}$. All of the synthesized compounds were screened for nitric oxide scavenging activity as well. Frontier molecular orbitals (FMOs) and molecular electrostatic potentials of the target compounds were also studied theoretically to account for their relative reactivity
\end{abstract}

Keywords: 2-bromo-5-chloro thiophenes; Suzuki coupling; density functional theory (DFT); antibacterial; antioxidant 


\section{Introduction}

Substituted aromatic compounds are widely synthesized by the well-established family of chemical reactions known as cross-coupling reactions [1,2]. Suzuki cross-coupling reactions generally deliver higher yields under mild reaction conditions, compared to other cross-coupling reactions. Moreover, the boronic acid is commercially available, and the reactions are environmentally friendly [3-6]. During the last three decades, carbon-carbon coupling for the synthesis of biaryls has replaced classical approaches such as Ullman coupling reactions [7]. Suzuki reaction of tetrabromothiophene is well reported [8-10]. The lower cost and easy availability of aryl chlorides made them attractive starting materials in Suzuki-Miyaura reaction with the help of wide varieties of catalytic systems [11-14].

Thiophene moiety is found to be very potent in various biological activities [15-17]. Anti-urease and nitric oxide (NO) scavenging activity of a series of 2-amino-6-arylbenzothiazoles were examined by Gul et al. [11]. Various 4-arylthiophene-2-carbaldehydes showed moderate to excellent ability against antibacterial, anti-urease, hemolytic, and antioxidant activities [16]. We became interested in synthesizing unsymmetrical bis-aryl ( $\mathrm{Ar}$ and $\mathrm{Ar}^{\prime}$ ) substituted thiophene by taking the advantage of difference of reactivity of chloro and bromo moiety on thiophene ring. Therefore, in this report, we extend the utilization of aryl chlorides and bromides by reporting the selective Suzuki coupling reactions of 2-bromo-5-chlorothiophene with various electron donating and electron withdrawing aryl boronic acids. These reactions allow efficient synthesis of mono substituted and di-substituted thiophenes by using $\mathrm{K}_{3} \mathrm{PO}_{4}$ as base. However, the compounds $\mathbf{2 a -} \mathbf{c}$ and $\mathbf{3 a}-\mathbf{c}$ have already been reported by following different methodologies [18-22], while their biological activities and density functional theory (DFT) studies are being first time reported. After accomplishing the successful synthesis of various mono and di substituted thiopehenes, in continuation of our previous work [23,24], DFT studies were conducted not only to explore the structural properties but also to compare the theoretical structural parameters with those from X-ray diffraction results. Finally, antibacterial and nitric oxide (NO) scavenging activity of the products were investigated.

\section{Results and Discussion}

\subsection{Preparations}

The 2-aryl-5-chlorothiophenes (2a-f) were synthesized via Suzuki reaction (Scheme 1) from commercially available (1) 2-bromo-5-chloro thiophene ( $1.0 \mathrm{mmol}$ ). The compounds $\mathbf{2 a} \mathbf{a}, \mathbf{2 b}$ and $\mathbf{2}$ chave been previously reported but through alternative synthetic strategies [25-28].

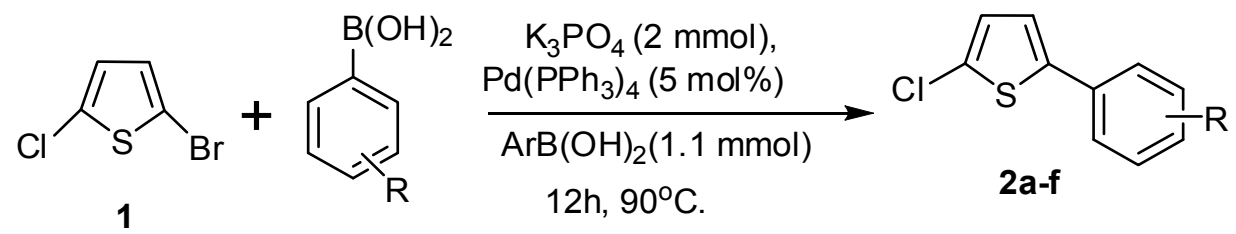

Scheme 1. Synthesis of compounds $2 \mathbf{a}-\mathbf{f} . \quad \mathbf{R}: \mathbf{2 a}=4-\mathrm{Me}, \mathbf{2 b}=4-\mathrm{MeO}, \mathbf{2 c}=4-\mathrm{Cl}, \mathbf{2 d}=3-\mathrm{Cl}, 4-\mathrm{F}$, $\mathbf{2 e}=3,5$-dimethyl, and $\mathbf{2} \mathbf{f}=3$,4-dichloro.

It should be noted that the $\mathrm{C}-\mathrm{Cl}$ bond strength hampers the reactivity of aryl chlorides, thus, they are reluctant to oxidative addition to $\operatorname{Pd}(0)$ [14]. Products $\mathbf{2 a}-\mathbf{f}$ were prepared following a protocol developed by us [29]. All the products showed moderate to very good yields in the presence of $\mathrm{K}_{3} \mathrm{PO}_{4}$ base (Figure 1). These results suggest that the yield might be sensitive to electron donating and electron withdrawing substituents present on the boronic acid. The base plays a vital role in Suzuki cross-coupling reactions, and it enhances the transmetallation process. Therefore, the choice of the solvent water ratio $(3: 1.5,5: 1.5 \mathrm{~mL})$ and the quantity of base used are essential to activate boronic acids, and help to obtain good yields. 
<smiles>Cc1ccc(-c2ccc(Cl)s2)cc1</smiles><smiles>COc1ccc(-c2ccc(Cl)s2)cc1</smiles><smiles>Clc1ccc(-c2ccc(Cl)s2)cc1</smiles><smiles>Cc1cc(-c2ccc(Cl)s2)ccc1F</smiles>

2d $(65 \%)$<smiles>Cc1cc(C)cc(-c2ccc(Cl)s2)c1</smiles><smiles>Clc1ccc(-c2ccc(Cl)c(Cl)c2)s1</smiles>

Figure 1. Scope of the compounds $2 \mathbf{a}-\mathbf{f}$.

The biarylthiophenes (3a-f) having two similar aryl groups were synthesized via Suzuki reaction of $\mathbf{1}(1.0 \mathrm{mmol}$ ) with (2.6 equiv.) of several aryl boronic acids (Scheme 2 ) in moderate to good yields (Figure 2). Reaction conditions such as solvent, temperature, and base played important in controlling the reaction especially for activating chloro functional group to obtain identical di-substituted products. During reaction, temperature was kept at $110^{\circ} \mathrm{C}$. This high temperature plays a significant role for breaking $\mathrm{C}-\mathrm{Cl}$ bond, and helps in the oxidative addition in Suzuki coupling reactions.

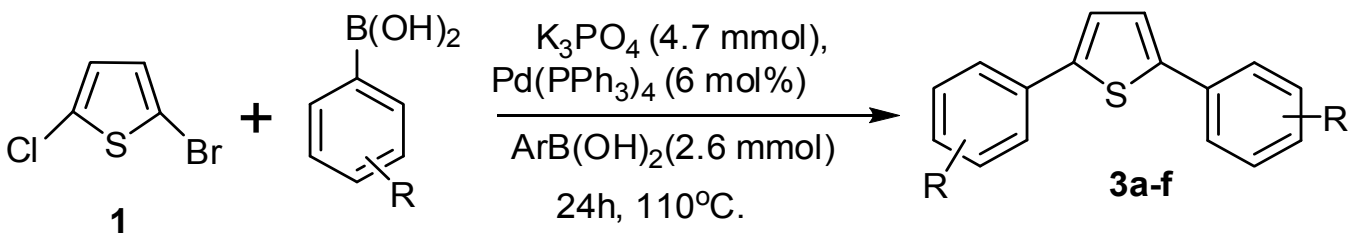

Scheme 2. Scope of the compounds of compounds $3 \mathbf{a}-\mathbf{f}$. $\mathbf{R}: \mathbf{3 a}=4-\mathrm{Me}, \mathbf{3 b}=4-\mathrm{MeO}, \mathbf{3 c}=4$-Chloro, $\mathbf{3 d}=3$-Chloro-4-fluoro, $\mathbf{3 e}=3$,5-dimethyl, and $\mathbf{3 f}=3$,4-dichloro.<smiles>Cc1ccc(-c2ccc(Cl)s2)cc1</smiles><smiles>Cc1cc(-c2ccc(Cl)s2)ccc1F</smiles>

2d $(65 \%)$<smiles>COc1ccc(-c2ccc(Cl)s2)cc1</smiles><smiles>Clc1ccc(-c2ccc(Cl)s2)cc1</smiles>

2c $(70 \%)$<smiles>Cc1cc(C)cc(-c2ccc(Cl)s2)c1</smiles><smiles>Clc1ccc(-c2ccc(Cl)c(Cl)c2)s1</smiles>

Figure 2. Synthesis of compounds $\mathbf{3 a}-\mathbf{f}$.

\subsection{Crystal Structure Determinations}

Among all synthesized derivatives, suitable crystals were obtained for $\mathbf{2} \mathbf{d}$ and $\mathbf{2} \mathbf{f}$ which were then subjected to X-ray radiation for their structure confirmation and to obtain geometric parameters and spatial interactions. ORTEP plots of both compounds are shown in the Figure 3, and X-ray parameters are being provided in Table 1 . The root mean square (RMS) deviation for $\mathbf{2} \mathbf{d}$ is $0.0287 \AA$, which 
is indicative of planarity from its fitted atoms with most deviations from $\mathrm{Cl} 2=-0.0596$ (2) $\AA$ and $\mathrm{C} 8=0.0420$ (4) $\AA$. On the other hand, $2 \mathbf{f}$ is not planar with the RMS deviation from the fitted atoms of the molecule at $0.1619 \AA$, with most deviations from C $8=-0.2746$ (2) $\AA$ and S1 $=0.2455$ (1) $\AA$. The aromatic ring is twisted at a dihedral angle of $11.789^{\circ}$ (2) and $2.115^{\circ}$ (2) for both, respectively. This also proves the more planarity of $\mathbf{2 d}$. The C-S-C angles in both molecules are 91.34 and 91.74 degrees, which is in accordance with already reported data [30]. The unit cell diagrams were shown in Figure 4 for compounds I and II, respectively, which does not show any inter- or intra-molecular interactions among the molecules.

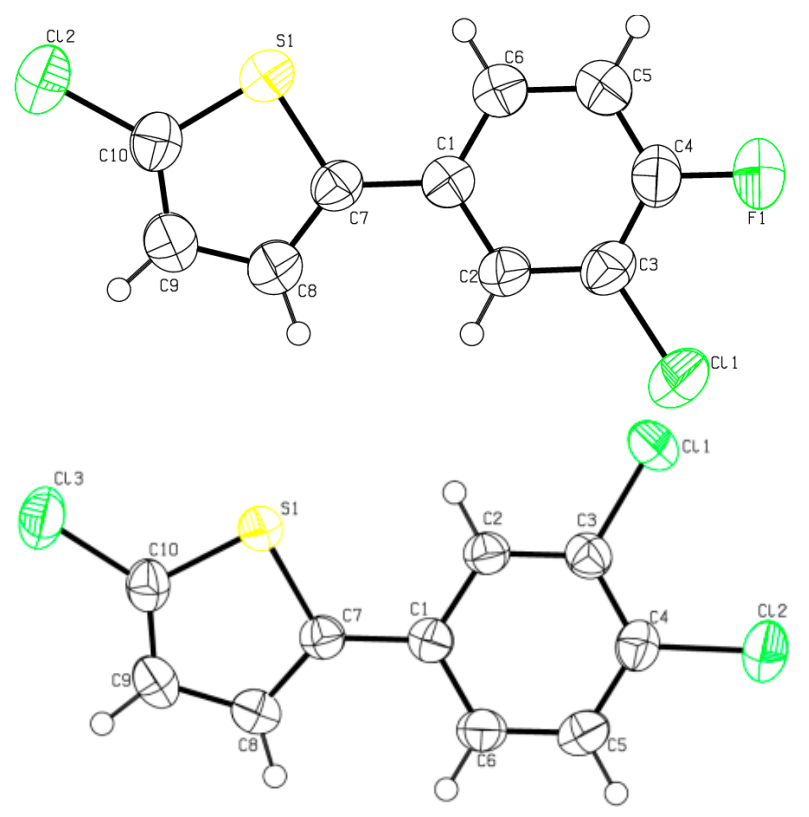

Figure 3. ORTEP plots of $\mathbf{2 d}$ and $\mathbf{2 f}$.
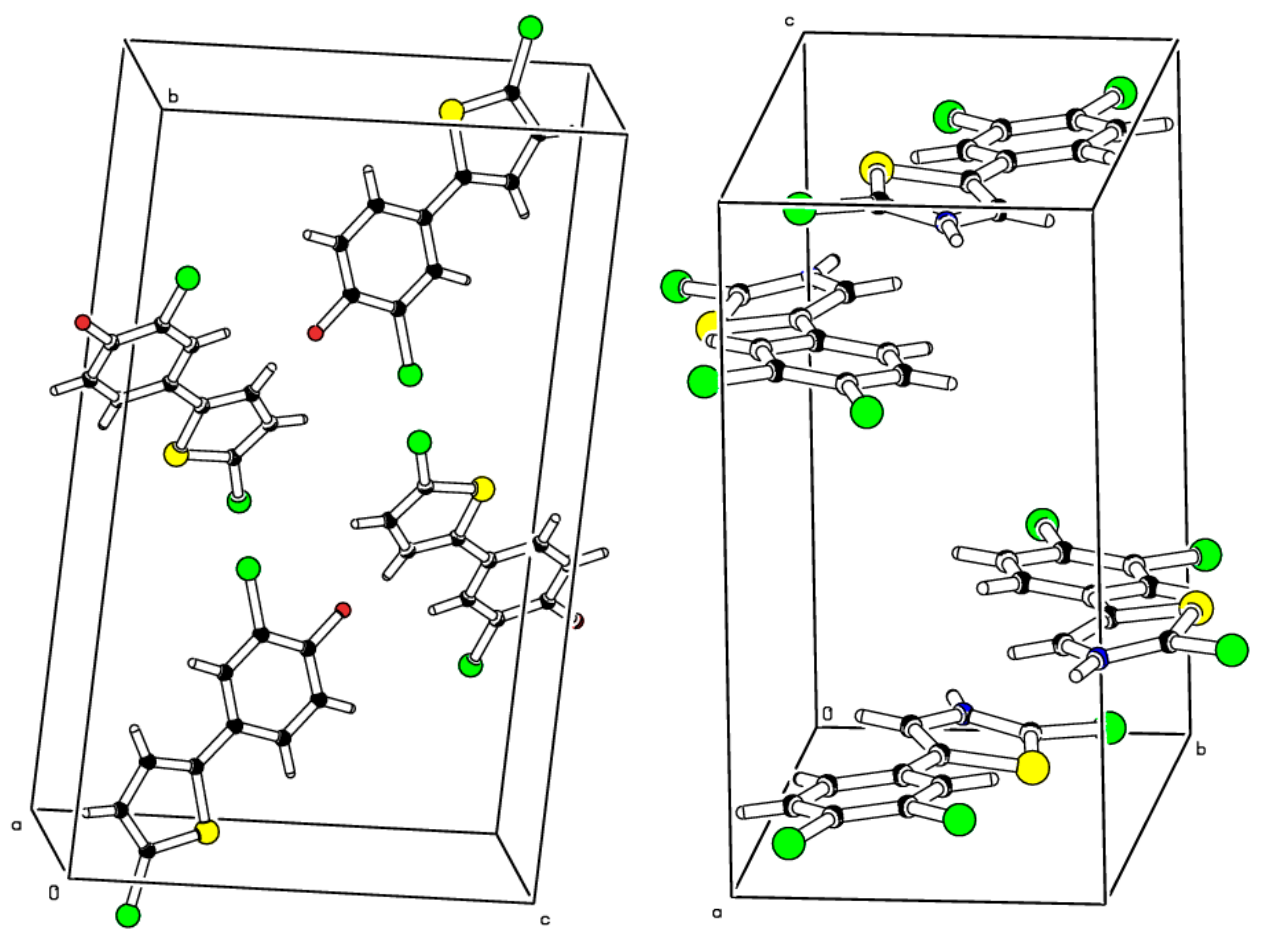

Figure 4. Unit cell diagrams of $\mathbf{2 d}$ and $\mathbf{2 f}$. (Ball color: green, Cl; red, F; yellow, S; black and blue, C). 
Table 1. Crystal data and structure refinement parameters for compounds $\mathbf{2} \mathbf{d}$ and $\mathbf{2} \mathbf{f}$.

\begin{tabular}{|c|c|c|}
\hline Compound & $2 d$ & $2 f$ \\
\hline Empirical formula & $\mathrm{C}_{10} \mathrm{H}_{5} \mathrm{Cl}_{2} \mathrm{SF}$ & $\mathrm{C}_{10} \mathrm{H}_{5} \mathrm{SCl}_{3}$ \\
\hline Formula weight & 247.10 & 263.55 \\
\hline Temperature/K & 293(2) & 293(2) \\
\hline Crystal system & monoclinic & monoclinic \\
\hline Space group & $\mathrm{P} 2_{1} / \mathrm{c}$ & $\mathrm{P} 2_{1} / \mathrm{n}$ \\
\hline $\mathrm{a} / \AA$ & $3.8805(3)$ & $11.3539(3)$ \\
\hline $\mathrm{b} / \AA$ & $21.8785(12)$ & $6.9384(2)$ \\
\hline$c / \AA$ & $11.9541(8)$ & $13.1916(4)$ \\
\hline$\alpha /{ }^{\circ}$ & 90 & 90 \\
\hline$\beta /{ }^{\circ}$ & $98.688(8)$ & $90.807(3)$ \\
\hline$\gamma /{ }^{\circ}$ & 90 & 90 \\
\hline Volume $/ \AA^{3}$ & 1003.25(12) & $1039.10(5)$ \\
\hline $\mathrm{Z}$ & 4 & 4 \\
\hline$\rho_{\text {calc }} \mathrm{g} / \mathrm{cm}^{3}$ & 1.636 & 1.685 \\
\hline$\mu / \mathrm{mm}^{-1}$ & 7.516 & 9.467 \\
\hline $\mathrm{F}(000)$ & 496.0 & 528.0 \\
\hline Crystal size $/ \mathrm{mm}^{3}$ & $0.26 \times 0.06 \times 0.06$ & $0.33 \times 0.18 \times 0.15$ \\
\hline Radiation & $\mathrm{CuK} \alpha(\lambda=1.54184)$ & $\mathrm{CuK} \alpha(\lambda=1.54184)$ \\
\hline $2 \theta$ range for data collection $/{ }^{\circ}$ & 8.082 to 162.368 & 10.208 to 152.446 \\
\hline Index ranges & $-4 \leqslant \mathrm{~h} \leqslant 4,-27 \leqslant \mathrm{k} \leqslant 25,-12 \leqslant 1 \leqslant 14$ & $-11 \leqslant \mathrm{~h} \leqslant 14,-8 \leqslant \mathrm{k} \leqslant 8,-16 \leqslant 1 \leqslant 16$ \\
\hline Reflections collected & 6585 & 10801 \\
\hline Independent reflections & $2064\left(R_{\text {int }}=0.0292, R_{\text {sigma }}=0.0228\right)$ & $2170\left(R_{\text {int }}=0.0324, R_{\text {sigma }}=0.0183\right)$ \\
\hline Data/restraints/parameters & $2064 / 0 / 127$ & $2170 / 0 / 127$ \\
\hline Goodness-of-fit on $\mathrm{F}^{2}$ & 0.981 & 1.015 \\
\hline Final $R$ indexes $(I \geqslant 2 \sigma(I))$ & $\mathrm{R}_{1}=0.0463, \mathrm{w} \mathrm{R}_{2}=0.1180$ & $\mathrm{R}_{1}=0.0303, \mathrm{wR}_{2}=0.0795$ \\
\hline Final R indexes (all data) & $\mathrm{R}_{1}=0.0643, \mathrm{w} \mathrm{R}_{2}=0.1466$ & $\mathrm{R}_{1}=0.0340, \mathrm{wR}_{2}=0.0830$ \\
\hline Largest diff. peak/hole/e $\AA^{-3}$ & $0.37 /-0.41$ & $0.27 /-0.30$ \\
\hline
\end{tabular}

\subsection{Density Functional Theory (DFT) Studies}

\subsubsection{Molecular Geometries}

Molecular geometries obtained through theoretical methods are very useful to explain the three-dimensional structures of compounds, and to compare them with the geometric parameters obtained from X-ray diffraction studies [31]. Among all of the synthesized thiophenes, only $\mathbf{2} \mathbf{d}$ and $2 \mathbf{f}$ gave suitable crystals for $\mathrm{X}$-ray diffraction studies (vide supra). Optimization of all compounds was carried out at B3LYP/6-31G (d, p) level of DFT optimized geometries of $\mathbf{2} \mathbf{d}$ and $\mathbf{2} \mathbf{f}$ are shown in Figure 5, whereas important bonds lengths and bond angles are listed in the Tables 2 and 3. $\mathrm{X}$-ray geometric parameters of both compounds $\mathbf{2} \mathbf{d}$ and $\mathbf{2 f}$ showed tight correlation with calculated results. The difference in X-ray and calculated bond lengths found in the range 0.003-0.035 $\AA$ and 0.002-0.028 $\AA$ for $\mathbf{2} \mathbf{d}$ and $\mathbf{2 f}$, simultaneously. Maximum deviation depicted for C10-S1 in both $\mathbf{2 d}$ and 2f, which is $0.035 \AA$ and $0.028 \AA$, respectively (atomic labelling is according to the ORTEP plots shown in Figure 5.
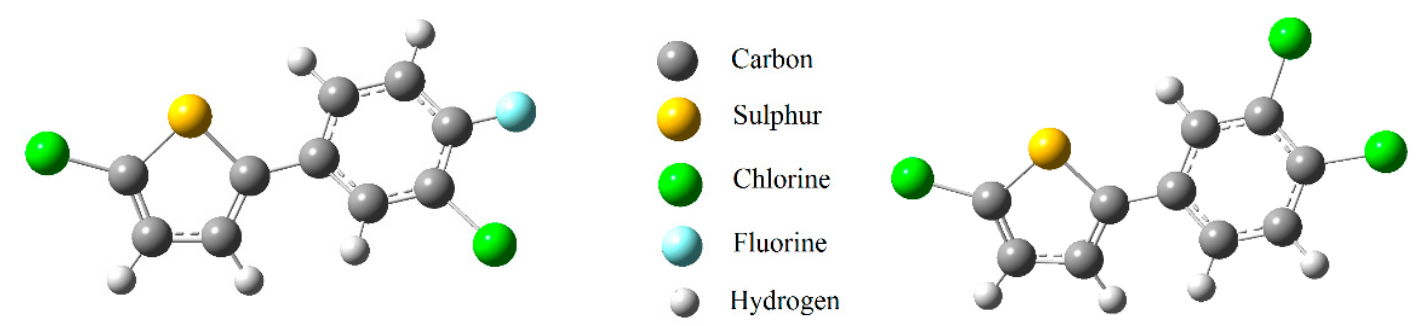

Figure 5. Optimized geometries of $\mathbf{2} \mathbf{d}$ and $\mathbf{2} \mathbf{f}$ at B3LYP/6-31G $(\mathrm{d}, \mathrm{p})$ level of DFT.

Similarly, the bond angles of both compounds correlated to each other excellently, very minute differences were observed in the range $0.0^{\circ}-0.9^{\circ}$ and $0.1^{\circ}-1.2^{\circ}$ for both compounds $2 \mathrm{~d}$ and $2 \mathrm{f}$, 
respectively. The maximum difference observed for C5-C4-C3 in 2d, i.e., $0.9^{\circ}$ and for C13-C10-S1 for $2 \mathbf{f}\left(1.2^{\circ}\right)$.

Table 2. Some selected X-ray and simulated bond lengths $(\AA)$ of $\mathbf{2 d}$ and $\mathbf{2 f}$ (atomic labels are with reference to ORTEP plot Figure 3).

\begin{tabular}{cccccc}
\hline $\mathbf{( 2 d )}$ & X-ray & Calc. (B3LYP) & (2f) & X-ray & Calc. (B3LYP) \\
\hline C1-C2 & $1.400(4)$ & 1.406 & C1-C2 & $1.399(2)$ & 1.405 \\
C1-C6 & $1.391(5)$ & 1.406 & C1-C6 & $1.401(2)$ & 1.404 \\
C1-C7 & $1.474(4)$ & 1.467 & C1-C7 & $1.464(2)$ & 1.466 \\
C2-C3 & $1.375(5)$ & 1.39 & C2-C3 & $1.374(2)$ & 1.389 \\
C3-C4 & $1.373(5)$ & 1.396 & C3-C4 & $1.387(3)$ & 1.396 \\
C3-C11 & $1.727(4)$ & 1.746 & C3-C11 & $1.728(18)$ & 1.747 \\
C4-C5 & $1.363(6)$ & 1.389 & C4-C5 & $1.386(3)$ & 1.401 \\
C5-C6 & $1.371(5)$ & 1.391 & C4-C12 & $1.726(18)$ & 1.745 \\
C7-C8 & $1.355(5)$ & 1.374 & C5-C6 & $1.374(3)$ & 1.392 \\
C7-S1 & $1.725(3)$ & 1.757 & C7-C8 & $1.369(2)$ & 1.375 \\
C8-C9 & $1.421(5)$ & 1.424 & C7-S1 & $1.734(18)$ & 1.757 \\
C9-C10 & $1.342(6)$ & 1.366 & C8-C9 & $1.415(3)$ & 1.423 \\
C10-S1 & $1.707(4)$ & 1.742 & C9-C10 & $1.346(3)$ & 1.366 \\
C10-C12 & $1.715(4)$ & 1.73 & C10-S1 & $1.714(18)$ & 1.742 \\
C4-F1 & $1.357(4)$ & 1.34 & C10-C13 & $1.714(2)$ & 1.73 \\
\hline
\end{tabular}

Table 3. Some selected X-ray and simulated bond angles $\left(^{\circ}\right)$ of $\mathbf{2} \mathbf{d}$ and $\mathbf{2 f}$ (atomic labels are with Reference to Figure 3).

\begin{tabular}{cccccc}
\hline Bond (2d) & X-ray & Calc. (B3LYP) & Bond (2f) & X-ray & Calc. (B3LYP) \\
\hline C2-C1-C6 & $118.0(3)$ & 118.4 & C2-C1-C6 & $117.7(16)$ & 118.1 \\
C2-C1-C7 & $120.3(3)$ & 119.7 & C2-C1-C7 & $121.1(16)$ & 121.4 \\
C6-C1-C7 & $121.7(3)$ & 121.8 & C6-C1-C7 & $121.0(16)$ & 120.4 \\
C3-C2-C1 & $120.3(3)$ & 120.7 & C3-C2-C1 & $121.1(17)$ & 121.1 \\
C2-C3-C4 & $119.7(3)$ & 119.7 & C2-C3-C4 & $120.1(17)$ & 120 \\
C2-C3-C11 & $120.9(3)$ & 120.5 & C2-C3-C11 & $118.8(15)$ & 118.5 \\
C4-C3-C11 & $119.5(3)$ & 119.6 & C4-C3-C11 & $120.9(14)$ & 121.4 \\
C5-C4-C3 & $121.3(3)$ & 120.4 & C3-C4-C12 & $121.1(15)$ & 121.7 \\
C6-C5-C4 & $119.4(4)$ & 119.6 & C5-C4-C3 & $119.5(17)$ & 119.1 \\
F1-C4-C3 & $119.1(4)$ & 119.9 & C5-C4-C12 & $119.2(15)$ & 119 \\
C5-C4-F1 & $119.6(4)$ & 119.5 & C6-C5-C4 & $120.3(18)$ & 120.6 \\
C5-C6-C1 & $121.2(3)$ & 120.9 & C5-C6-C1 & $120.9(17)$ & 120.8 \\
C1-C7-S1 & $120.6(2)$ & 121.1 & C1-C7-S1 & $120.4(13)$ & 121.3 \\
C8-C7-C1 & $129.2(3)$ & 128.5 & C8-C7-C1 & $129.4(17)$ & 128.3 \\
C8-C7-S1 & $110.3(3)$ & 110.3 & C8-C7-S1 & $110.0(14)$ & 110.3 \\
C7-C8-C9 & $113.7(4)$ & 114.1 & C7-C8-C9 & $113.9(17)$ & 114.1 \\
C10-C9-C8 & $111.8(4)$ & 111.9 & C10-C9-C8 & $111.6(17)$ & 111.9 \\
C9-C10-S1 & $112.5(3)$ & 112.4 & C9-C10-S1 & $112.9(15)$ & 112.4 \\
C10-S1-C7 & $91.74(17)$ & 91.1 & C9-C10-C13 & $127.7(15)$ & 127 \\
S1-C10-C12 & $120.4(2)$ & 120.5 & C13-C10-S1 & $119.2(12)$ & 120.4 \\
C9-C10-C12 & $127.1(3)$ & 127 & C10-S1-C7 & $91.34(9)$ & 91 \\
\hline
\end{tabular}

\subsubsection{Frontier Molecular Orbital (FMOs) Analysis}

FMOs analysis by computational methods is a useful to understand the reactivity and electronic transitions within molecules [32].

Frontier orbitals (HOMO and LUMO), mainly take part in electronic transitions and their energy gap depicts the reactivity [33]. The HOMO-LUMO and electronic properties of compounds (2a-f) and (3a-f) were explored at 6-31G (d, p) level of DFT. The distribution patterns of frontier molecular orbitals (HOMOs and LUMOs along with corresponding energies) of all synthesized thiophene derivatives at the ground states have been shown in Figure 6. As reflected from Figure 6, the $\pi$ cloud in HOMOs 
and LUMOs of all thiophenes $(\mathbf{2 a}-\mathbf{f})$ and $(\mathbf{3 a}-\mathbf{f})$ is distributed on the entire skeleton (thiophene and phenyl rings). Introducing the different groups on the benzene ring does not have much effect on the electronic cloud. As reflected form orbital surfaces of compounds $\mathbf{2 a}, \mathbf{2 b}, \mathbf{2 c}, \mathbf{3 a}, \mathbf{3 b}$, and $\mathbf{3}$, groups attached to the para position of the benzene ring are participating in the $\pi$ electronic cloud. Whereas the groups attached to the meta position such as in compounds $\mathbf{2 d}, \mathbf{2 e}, \mathbf{3 d}$, and $\mathbf{3 e}$ are not involved directly in the $\pi$ electronic cloud.

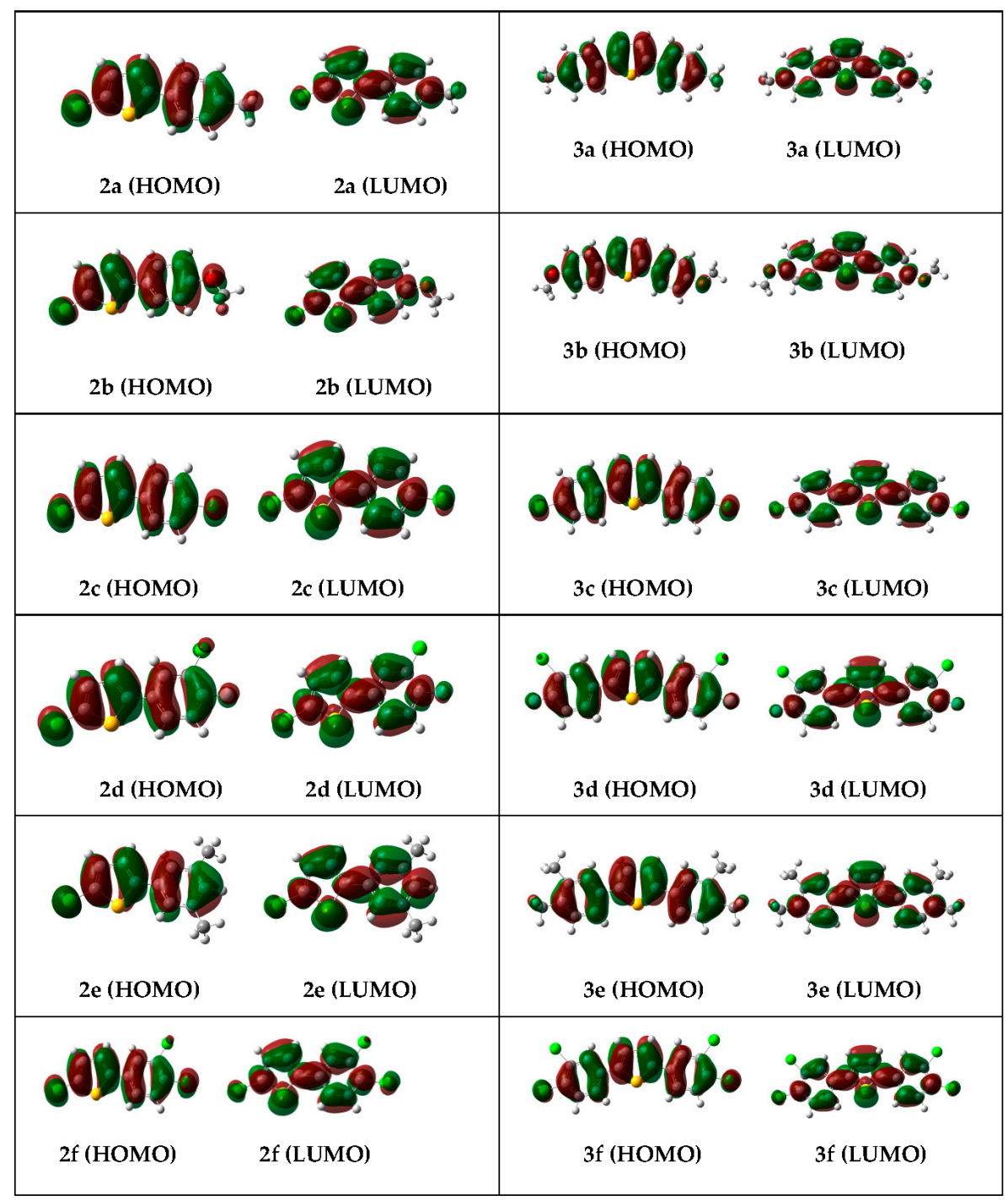

Figure 6. HO/LU orbitals of 2a-f and 3a-f.

Detailed HOMO and LUMO energies of all thiophenes along with their gaps are listed in the Table 4. HOMO-LUMO energy difference $\left(\mathrm{E}_{\mathrm{g}}\right)$ of mono aryl thiophenes $\mathbf{2 a}-\mathbf{f}$ is relatively large compare to bis-aryl thiophenes $\mathbf{3 a}-\mathbf{f}$. Among all synthesized compounds $\mathbf{3} \mathbf{b}$ and $\mathbf{3} \mathbf{f}$ showed the lowest HOMO-LUMO energy gap i.e., of $3.96 \mathrm{eV}$ and $\mathbf{2 e}$ showed the largest energy gap (4.59 eV). 
Table 4. HOMO and LUMO energies along with energy gaps.

\begin{tabular}{cccc}
\hline Entry No. & HOMO $(\mathbf{e V})$ & LUMO $(\mathbf{e V})$ & HOMO-LUMO $(\Delta \mathbf{E}) \mathbf{e V}$ \\
\hline $\mathbf{2 a}$ & -5.71 & -1.14 & 4.57 \\
$\mathbf{2 b}$ & -5.49 & -1.02 & 4.47 \\
$\mathbf{2 c}$ & -5.96 & -1.46 & 4.50 \\
$\mathbf{2 d}$ & -6.07 & -1.48 & 4.59 \\
$\mathbf{2} \mathbf{e}$ & -5.72 & -1.13 & 4.59 \\
$\mathbf{2 f}$ & -6.13 & -1.66 & 4.47 \\
$\mathbf{3 a}$ & -5.24 & -1.21 & 4.03 \\
$\mathbf{3 b}$ & -4.97 & -1.01 & 3.96 \\
3c & -5.68 & -1.70 & 3.98 \\
$\mathbf{3 d}$ & -5.84 & -1.76 & 4.08 \\
$\mathbf{3 e}$ & -5.16 & -1.14 & 4.02 \\
$\mathbf{3 f}$ & -5.96 & -1.99 & 3.97 \\
\hline
\end{tabular}

\subsubsection{Molecular Electrostatic Potential (MEP)}

Electrostatic potential (ESP) mapping through computer aided methods is very useful parameter to explore the reactivity of organic compounds. Molecular electrostatic potential (MEP) has been applied successfully to understand the enzyme-substrate interactions [34], hydrogen bonding [35], and nuclephilic as well as electrophilic sites in compounds [33].

The nucleophilic, as well as electrophilic, sites in any compound are expressed in term of different color codes, the deep red colour expresses an electron rich site, whereas deep blue expresses an electron-deficient site (Figure 7). From the MEP shown in Figure 7, it is clear that electronic density in 2a is concentrated on the chloro as well as sulphur atoms of the thiophene ring along with the pi cloud of benzene ring, and protons attached to the thiophene and benzene ring are electron deficient sites. Almost the same trend was observed for $\mathbf{2} \mathbf{b}$ and $\mathbf{3} \mathbf{b}$ but with some extra localization of electronic density on methoxy group oxygen directly attached to benzene. In $\mathbf{2 c}, \mathbf{2 d}, \mathbf{2 f}, \mathbf{3 c}, \mathbf{3 d}$, and $\mathbf{3 f}$ electronic density was more dispersed and concentrated on chloro and floro groups, due to their electron withdrawing nature and positive potential is concentrated on the protons attached to the thiophene and benzene rings. Compounds $\mathbf{2 e}$ and $\mathbf{3 e}$ are bearing the electron-donating methyl groups attached to the rings; therefore, the electronic density is localized on the pi cloud of both the thiophene and benzene rings.

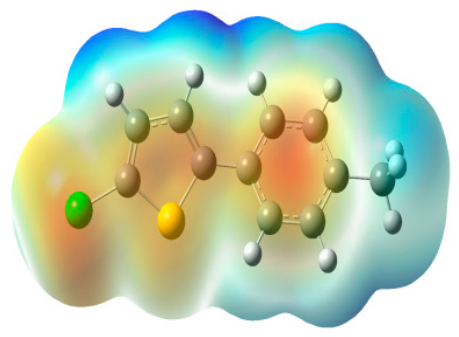

2a

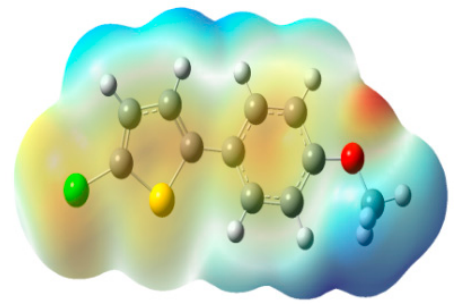

$2 b$

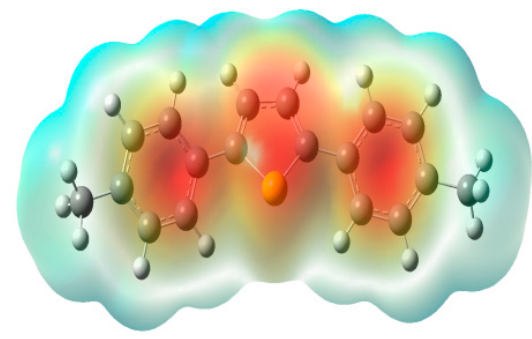

$3 a$

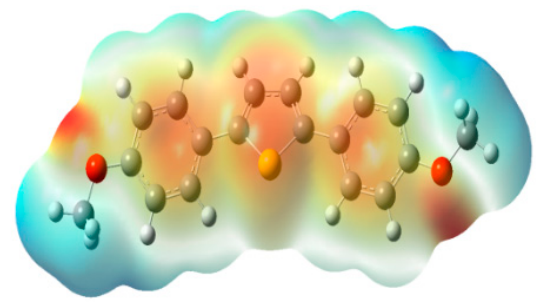

$3 b$

Figure 7. Cont. 


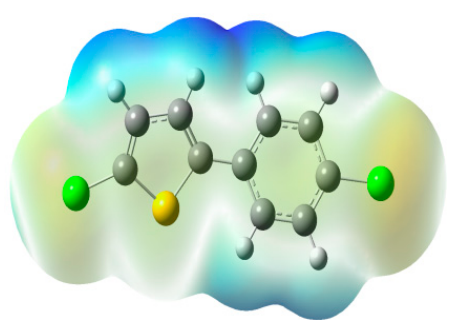

2c

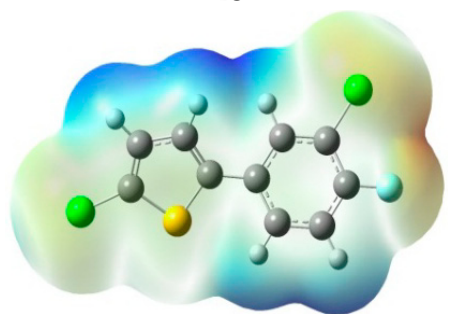

2d

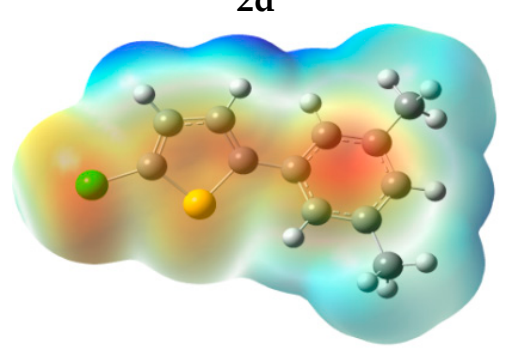

$2 e$

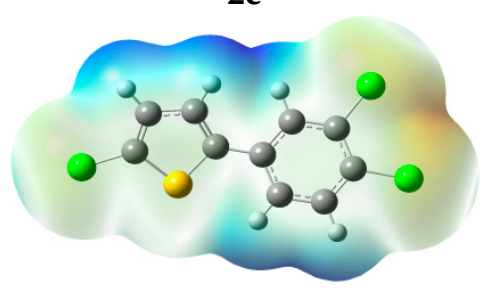

$2 f$

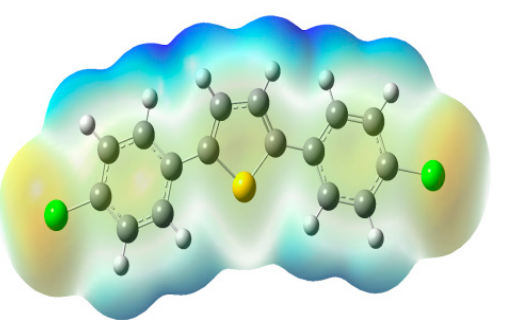

$3 c$

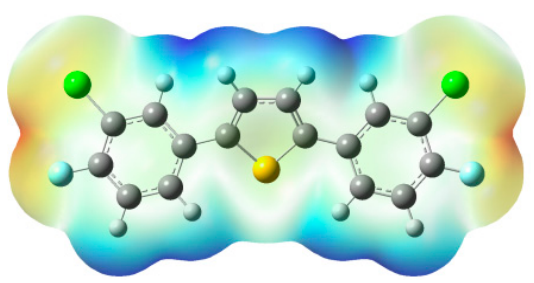

$3 d$

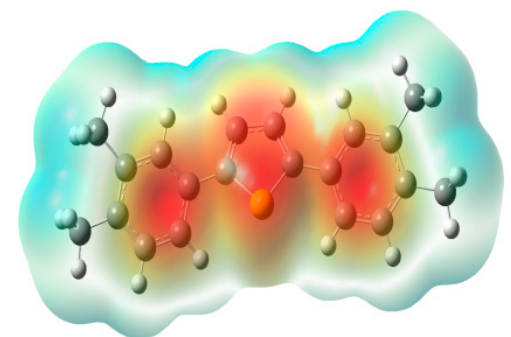

$3 e$

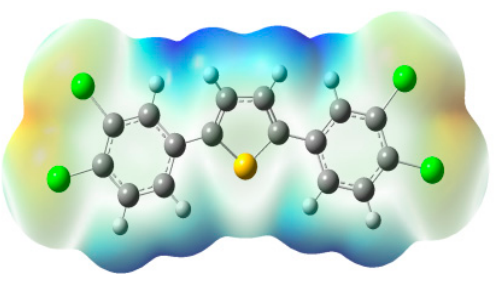

$3 f$

Figure 7. Molecular electrostatic potential (MEP) graphics of mono substituted (2a-f) and di-substituted $(3 \mathbf{a}-\mathbf{f})$ thiophenes $(\operatorname{Red}=$ Intense electron rich site, Yellow $=$ Medium electron rich site site, Blue $=$ Electron deficient site, Light green $=$ Almost neutral site, Grey $=$ White $=$ Zero potential) .

\section{Biological Studies}

\subsection{Antibacterial Activity}

Antibacterial activity is related to the existence of some elements in a compound, such as sulfur [8,36-38]. Recently, benzothiophene derivatives have been used in many therapies [39]. The newly-synthesized thiophene molecules $2 \mathrm{a}$ to $\mathbf{3 f}$ were tested against several strains of Gram-negative bacteria (Eschericha coli, Shigella dysenteriae, Pseudomonas aeruginosa and Salmonella typhi) and Gram-positive bacteria (Staphylococcus aureus and Bacillus subtilis). Ampicillin was used as a standard drug, and all data are shown in Figure 8. Electron-withdrawing and electron-donating substituents have great effect on antibacterial activity of synthesized compounds [38]. At the concentration of 50 and $100 \mu \mathrm{g} / \mathrm{mL}$, compounds $\mathbf{2 c}, \mathbf{2 d}, \mathbf{3 c}$, and $\mathbf{3 f}$ (containing electron-withdrawing groups) with an $\mathrm{IC}_{50}$ value of $52.10,58.0,56.2$, and $56.5 \mu \mathrm{g} / \mathrm{mL}$, respectively, were found most potent against $E$. coli. Surprisingly, it has been observed that $\mathbf{2 b}$ exhibited highest bacterial inhibition activity with an $\mathrm{IC}_{50}$ value of $51.4 \mu \mathrm{g} / \mathrm{mL}$ and $2 \mathbf{a}$ also showed unexpected $\mathrm{IC}_{50}$ value of $54.17 \mu \mathrm{g} / \mathrm{mL}$, and both of these compounds contain electron-donating groups. Compounds $\mathbf{2 e}$ and $\mathbf{3} \mathbf{d}$ exhibited significant activity with an $\mathrm{IC}_{50}$ value of 70.5 and $71.2 \mu \mathrm{g} / \mathrm{mL}$. However $3 \mathbf{b}$ showed $\mathrm{IC}_{50}$ value almost equal to 
standard Ampicillin while the remaining compounds exhibited $\mathrm{IC}_{50}$ values more than the standard against $E$. coli and were found less active.

Compounds $\mathbf{2 b}, \mathbf{2} \mathbf{d}$, and $\mathbf{3 b}$ with an $\mathrm{IC}_{50}$ value of $80.0,80.9$, and $79.52 \mu \mathrm{g} / \mathrm{mL}$, respectively, showed moderate activity against $S$. typhi. However, $\mathbf{3 d}$ exhibited $\mathrm{IC}_{50}$ value nearly equal to the standard while all other compounds were found less active than the standard having a high value of $\mathrm{IC}_{50}$ as compared to the standard.

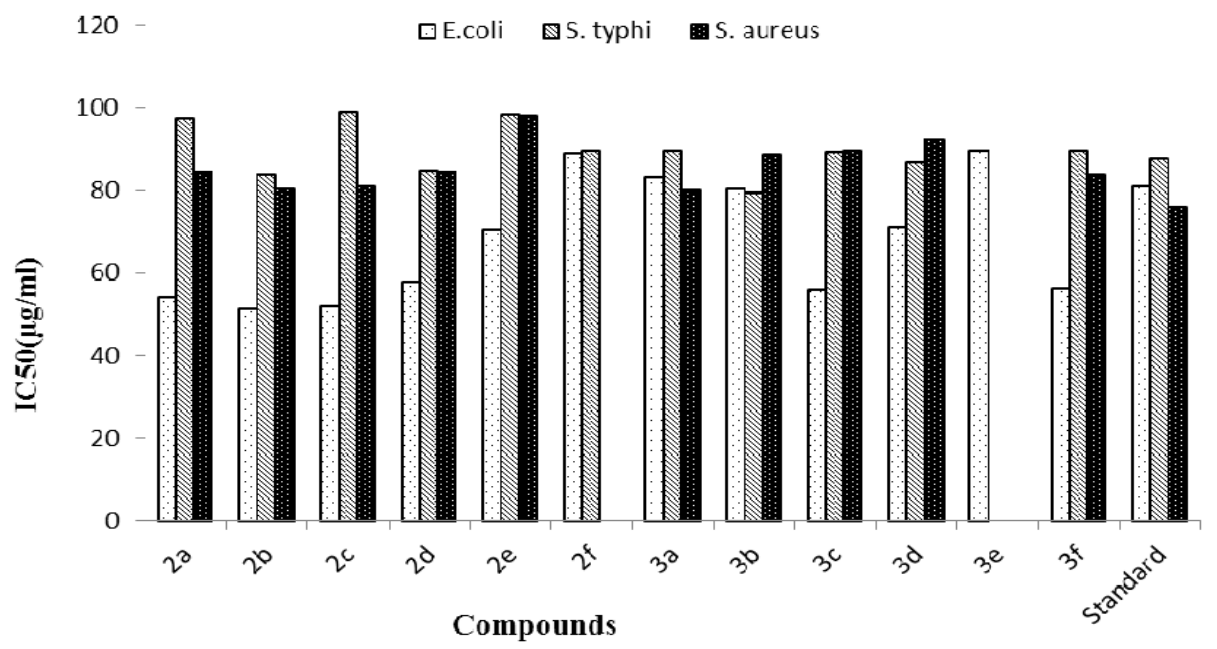

Figure 8. $\mathrm{IC}_{50}$ values of antibacterial activity.

\subsection{Antioxidant Activity}

Inflammatory disorders in the human body are associated with nitric oxide (NO). From the reported data, it is observed that various thiophene derivatives exhibit antioxidant activity [39-42] and can also be used as antitumor agent [43].

The antioxidant activity of compounds $2 \mathbf{a}-\mathbf{3} \mathbf{f}$ was tested by nitric oxide scavenging activity method and the results were compared with that of standard natural antioxidant ascorbic acid. As shown in Figure 9, almost all the synthesized compounds showed radical scavenging activity, but the highest scavenger activity was observed in the compound $3 \mathbf{d}$ whose $\mathrm{IC}_{50}$ value was 72 . Among all the synthesized compounds $\mathbf{2 a}, \mathbf{2 d}, \mathbf{3} \mathbf{c}$, and $\mathbf{3 e}$ with the least values of $\mathrm{IC}_{50} 77,76.26,79.13$ and $77.4 \mu \mathrm{g} / \mathrm{mL}$, respectively, showed significant antioxidant activities. Moderate nitric oxide scavenging activity was observed in all the remaining compounds, except $\mathbf{2 f}$, which is found inactive against this activity.

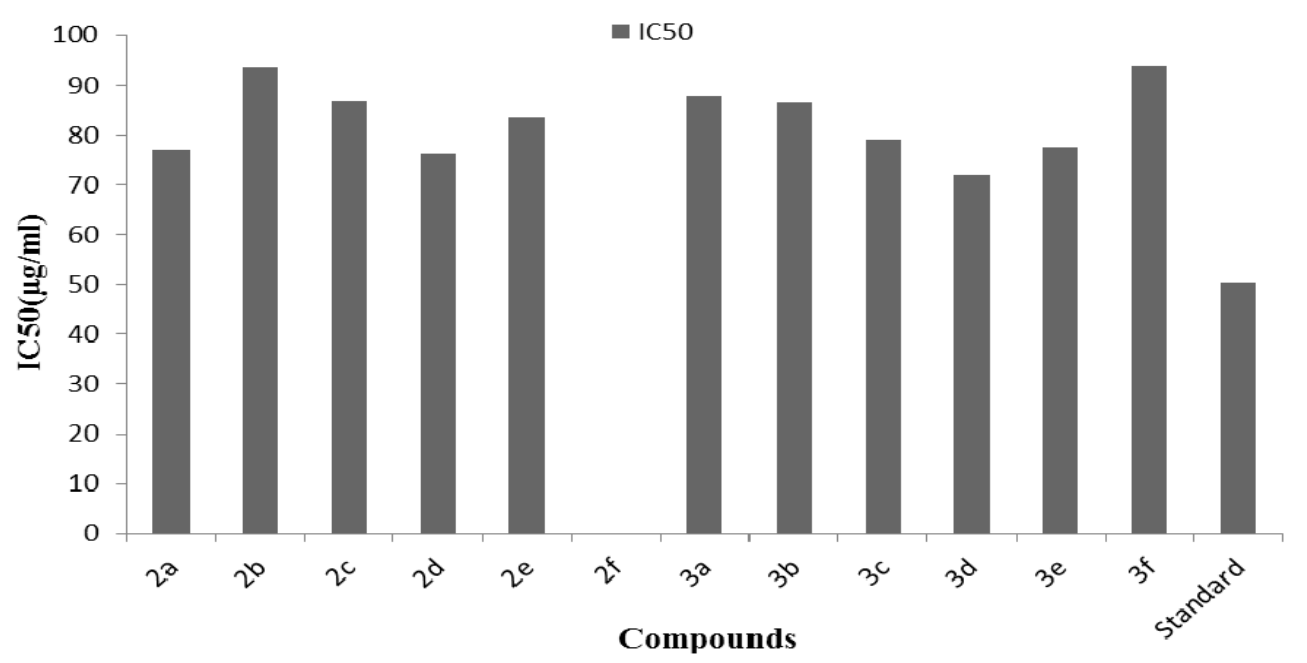

Figure 9. $\mathrm{IC}_{50}$ values of nitric oxide scavenging activity. 


\section{Materials and Methods}

A Bruker ARX $600 \mathrm{MHz}$ FT-NMR spectrometer (Billerica, MA, USA) was used to study. NMR spectra were taken on a Bruker ARX $600 \mathrm{MHz}$ FT-NMR spectrometer while relishing deuterated $\mathrm{CDCl}_{3}$ as internal reference.

\subsection{Synthesis of 2-Aryl-5-chloro thiophenes (2a-f)}

To a stirred solution of $3 \mathrm{~mL}$ dioxane of 2-bromo-5-chlorothiophene $(1.0 \mathrm{mmol})$ and tetrakis(triphenylphosphine)palladium(0) $(5.0 \mathrm{~mol} \%)$ were added and stirred for a period of $30 \mathrm{~min}$. To this mixture was added $\mathrm{Ar}-\mathrm{B}(\mathrm{OH})_{2}(1.1 \mathrm{mmol})$, water $(1.5 \mathrm{~mL})$ and 2-mmol of $\mathrm{K}_{3} \mathrm{PO}_{4}$. The mixture was stirred at $90^{\circ} \mathrm{C}$ for a period of $12 \mathrm{~h}$. With the help of column chromatography the resultant product was purified.

\subsubsection{2-Chloro-5-(4-methylphenyl) thiophene (2a)}

Pale yellow solid, mp. $168{ }^{\circ} \mathrm{C},{ }^{1} \mathrm{H}-\mathrm{NMR}: \delta=7.38(\mathrm{~d}, J=7.9,2 \mathrm{H}-\mathrm{Ar}), 7.16(\mathrm{~d}, J=8,2 \mathrm{H}-\mathrm{Ar})$, $7.00\left(\mathrm{~d}, J=4,1 \mathrm{H}\right.$-Thiophene), $6.85\left(\mathrm{~d}, J=3.6,1 \mathrm{H}\right.$ Thiophene), $2.36\left(\mathrm{~s}, 3 \mathrm{H}-\mathrm{CH}_{3}\right) .{ }^{13} \mathrm{C}-\mathrm{NMR}: \delta=21.2\left(\mathrm{CH}_{3}\right.$ of aryl), 125.7, 127.1, 127.4, 129.8, 130.2, 132.0, 138.9. EIMS $m / z: 208.71 ;\left[\mathrm{M}+\mathrm{H}^{+}\right]:[\mathrm{M}-\mathrm{Cl}]^{+}=172.26$; $\left[\mathrm{M}-\mathrm{CH}_{3} \text { and benzene }\right]^{+}=91.14$. Anal. $(\%)$ calcd for $\mathrm{C}_{11} \mathrm{H}_{9} \mathrm{ClS}, \mathrm{C} 63.60, \mathrm{H}$ 4.35; found C 63.66, $\mathrm{H} 4.31$.

\subsubsection{2-Chloro-5-(4-methoxyphenyl) thiophene (2b)}

Light green solid, $\mathrm{mp} .172{ }^{\circ} \mathrm{C} ;{ }^{1} \mathrm{H}-\mathrm{NMR}: \delta=7.40(\mathrm{~d}, J=8.3,2 \mathrm{H}-\mathrm{Ar}), 7.01(\mathrm{~d}, J=3.6,1 \mathrm{H}-$ Thiophene), $6.90(\mathrm{~d}, J=8.8,2 \mathrm{H}-\mathrm{Ar}), 6.85\left(\mathrm{~d}, J=3.8,1 \mathrm{H}\right.$ Thiophene) $3.81\left(\mathrm{~s}, 3 \mathrm{OCH}_{3}\right) .{ }^{13} \mathrm{C}-\mathrm{NMR}: \delta=56.1\left(\mathrm{OCH}_{3}\right.$ of aryl), 115.0, 125.8, 126.3, 127.3, 127.9, 139.5, 160.9. EIMS $m / z: 224.71 ;[\mathrm{M}+\mathrm{H}]^{+}:[\mathrm{M}-\mathrm{OMe}]^{+}=194.68$; $[\mathrm{M}-\mathrm{Cl}]^{+}=190.26$. Anal. $(\%)$ calcd for $\mathrm{C}_{11} \mathrm{H}_{9} \mathrm{ClOS}, \mathrm{C} 58.80 ; \mathrm{H} 4.04$; found C 58.20, H 4.10.

\subsubsection{2-Chloro-5-(4-chlorophenyl) thiophene (2c)}

Yellowish green solid, mp. $180{ }^{\circ} \mathrm{C} ;{ }^{1} \mathrm{H}-\mathrm{NMR}: \delta=7.42(\mathrm{~d}, J=7.2,2 \mathrm{H}-\mathrm{Ar}), 7.35(\mathrm{~d}, J=8,2 \mathrm{H}-\mathrm{Ar})$, $7.10\left(\mathrm{~d}, J=3.5,1 \mathrm{H}\right.$ Thiophene), $6.89\left(\mathrm{~d}, J=3.8,1 \mathrm{H}\right.$ Thiophene). ${ }^{13} \mathrm{C}-\mathrm{NMR}: \delta=125.9,127.1,128.4,129.9$, 132.0, 134.6, 139.1. EIMS $m / z: 229.13 ;[\mathrm{M}+\mathrm{H}]^{+}:[\mathrm{M}-\mathrm{Cl}]^{+}=194.68 ;[\mathrm{M}-2 \mathrm{Cl}]^{+}=160.24$. Anal.(\%) calcd for $\mathrm{C}_{10} \mathrm{H}_{6} \mathrm{Cl}_{2} \mathrm{~S}, \mathrm{C} 52.46, \mathrm{H} 2.69$; found C $52.42 ; \mathrm{H} 2.64$. EIMS ( $m / z$, +ion mode).

\subsubsection{2-Chloro-5-(3-chloro-4-fluorophenyl) thiophene (2d)}

Yellow solid, mp. $185{ }^{\circ} \mathrm{C} ;{ }^{1} \mathrm{H}-\mathrm{NMR}: \delta=7.32(\mathrm{~m}, 3 \mathrm{H}-\mathrm{Ar}), 6.98$ (d, $J=4,1 \mathrm{H}$-Thiophene), $6.87\left(\mathrm{~d}, J=3.8,1 \mathrm{H}\right.$-Thiophene). ${ }^{13} \mathrm{C}-\mathrm{NMR}: \delta=117.8,121.3,126.0,126.8,127.6,128.8,130.1,138.9$, 158.2. EIMS $m / z: 247.12 ;\left[\mathrm{M}+\mathrm{H}^{+}\right]:[\mathrm{M}-\mathrm{F} \text { and } \mathrm{Cl}]^{+}=192.68$. Anal.(\%) calcd for $\mathrm{C}_{10} \mathrm{H}_{5} \mathrm{Cl}_{2} \mathrm{FS}, \mathrm{C} 48.58$; H 2.08, found C 48.60; H 2.04.

\subsubsection{2-Chloro-5-(3,5-dimethylphenyl) thiophene (2e)}

Greenish yellow solid, mp. $166{ }^{\circ} \mathrm{C} ;{ }^{1} \mathrm{H}-\mathrm{NMR}: \delta=7.30-7.19$ (m, 3H-Ar), $7.01(\mathrm{~d}, J=3.5$, 1H-Thiophene), $6.99\left(\mathrm{~d}, J=3.7,1 \mathrm{H}\right.$, Thiophene), $3.27\left(\mathrm{~s}, 6 \mathrm{H}-\mathrm{CH}_{3}\right) .{ }^{13} \mathrm{C}-\mathrm{NMR}: \delta=21.8\left(\mathrm{CH}_{3}\right.$ of aryl), 125.1, 126.1, 126.6, 127.5, 128.1, 128.9, 131.3, 138.8. EIMS $m / z: 222.73 ;\left[\mathrm{M}+\mathrm{H}^{+}\right]:[\mathrm{M}-\mathrm{Br}$ and $\left.2 \mathrm{CH}_{3}\right]^{+}=157.24$. Anal.(\%) calcd for $\mathrm{C}_{12} \mathrm{H}_{11} \mathrm{ClS}, \mathrm{C} 64.71, \mathrm{H} 4.98$, found C 64.77; $\mathrm{H} 4.93$.

4.1.6. 2-Chloro-5-(3,4-dichlorophenyl) thiophene (2f)

Brownish yellow solid, mp. $186{ }^{\circ} \mathrm{C} ;{ }^{1} \mathrm{H}-\mathrm{NMR}: \delta=7.47-7.30(\mathrm{~m}, 3 \mathrm{H}$-aryl) $7.20(\mathrm{~d}, J=3.8,1 \mathrm{H}$ Thiophene), 7.01 (d, $J=3.3,1 \mathrm{H}$ Thiophene). ${ }^{13} \mathrm{C}-\mathrm{NMR}: \delta=126.2,127.2,127.7,128.4,130.3,132.4,133.6$, 133.9, 139.1. EIMS $m / z$ : 263.57; $\left[\mathrm{M}+\mathrm{H}^{+}\right]:[\mathrm{M}-3 \mathrm{Cl}]^{+}=157.24 ;[\mathrm{M}-2 \mathrm{Cl} \text { and benzene }]^{+}=117.57$. Anal.(\%) calcd for $\mathrm{C}_{10} \mathrm{H}_{5} \mathrm{Cl}_{3} \mathrm{~S}, \mathrm{C} 45.52, \mathrm{H} 1.89$, found C $45.57 ; \mathrm{H} 1.91$. 


\subsection{Synthesis of Biarylthiophenes ( $3 a-f)$}

Stirred solution of $\mathbf{1}(1.0 \mathrm{mmol})$ and tetrakis(triphenylphosphine)palladium(0) $(6.0 \mathrm{~mol} \%)$ were added and stirred for a period of $30 \mathrm{~min}$. To this mixture was added $\mathrm{Ar}-\mathrm{B}(\mathrm{OH})_{2}(2.6 \mathrm{mmol})$, water $(1.5 \mathrm{~mL})$ and $4.7-\mathrm{mmol}$ of $\mathrm{K}_{3} \mathrm{PO}_{4}$. The mixture was stirred at $90^{\circ} \mathrm{C}$ for a period of $12 \mathrm{~h}$. The mixture was stirred at $110{ }^{\circ} \mathrm{C}$ for a period of $24 \mathrm{~h}$. With the help of column chromatography the resultant product was purified.

\subsubsection{2,5-Bis(4-methylphenyl) thiophene (3a)}

Pale yellow solid, mp. $191{ }^{\circ} \mathrm{C} ;{ }^{1} \mathrm{H}$-NMR: $\delta=7.05$ (s, 2H-thiophene), 7.39-7.20 (m, 8H-Ar), $3.02\left(\mathrm{~s}, 6 \mathrm{H}-\mathrm{CH}_{3}\right) .{ }^{13} \mathrm{C}-\mathrm{NMR}: \delta=21.1\left(\mathrm{CH}_{3}\right.$ of aryl $), 125.7,128.6,129.8,130.9,131.2,137.4,138.1$. EIMS $m / z: 264.38\left[\mathrm{M}+\mathrm{H}^{+}\right]:\left[\mathrm{M}-2 \mathrm{CH}_{3}\right]^{+}=234.33$. Anal.(\%) calcd for $\mathrm{C}_{18} \mathrm{H}_{16} \mathrm{~S}, \mathrm{C} 81.77, \mathrm{H}$ 6.10, found C 81.71; H 6.17.

\subsubsection{2,5-Bis(4-methoxyphenyl) thiophene (3b)}

Greenish white solid, mp. $17{ }^{\circ} \mathrm{C} ;{ }^{1} \mathrm{H}-\mathrm{NMR}: \delta=7.07$ (s, 2H-Thiophene), 7.33-7.30 (m, 8H-Ar), $3.79\left(\mathrm{~s}, 6 \mathrm{H}-\mathrm{OCH}_{3}\right) .{ }^{13} \mathrm{C}-\mathrm{NMR}: \delta=55.4\left(\mathrm{OCH}_{3}\right.$ of $\left.\operatorname{aryl}\right), 115.2,125.9,128.6,137.4,160.8$. EIMS $\mathrm{m} / \mathrm{z}$ : $296.28\left[\mathrm{M}+\mathrm{H}^{+}\right]:\left[\mathrm{M}-\mathrm{OCH}_{3}\right]^{+}=265.36$; $\left[\mathrm{M}-\mathrm{OCH}_{3} \text { and benzene }\right]^{+}=189.26$. Anal. $(\%)$ calcd for $\mathrm{C}_{18} \mathrm{H}_{16} \mathrm{O}_{2} \mathrm{~S}, \mathrm{C} 79.91, \mathrm{H}$ 5.40, found C 79.94; $\mathrm{H}$ 5.44.

\subsubsection{2,5-Bis(4-chlorophenyl) thiophene (3c)}

Yellow solid, mp. $196{ }^{\circ} \mathrm{C} ;{ }^{1} \mathrm{H}-\mathrm{NMR}: \delta=7.05$ (s, 2H-Thiophene), 7.41-7.30 (m, 8H-Ar). ${ }^{13} \mathrm{C}-\mathrm{NMR}$ : $\delta=128.2,129.5,130.9,134.6,137.3$. EIMS $m / z: 305.21[\mathrm{M}+\mathrm{H}]^{+}:[\mathrm{M}-2 \mathrm{Cl}]^{+}=234.31:[\mathrm{M}-\mathrm{Cl}$ and benzene $]^{+}=193.76$. Anal. (\%) calcd for $\mathrm{C}_{18} \mathrm{H}_{16} \mathrm{O}_{2} \mathrm{~S}, \mathrm{C} 62.90, \mathrm{H} 3.38$, found C 62.96; H 3.30.

\subsubsection{2,5-Bis(3-chloro-4-fluorophenyl) thiophene (3d)}

Yellow crystals, mp. $183{ }^{\circ} \mathrm{C} ;{ }^{1} \mathrm{H}-\mathrm{NMR}: \delta=7.20$ (s, 2H-Thiophene), 7.69-7.58 (m, 6H-Ar). ${ }^{13}$ C-NMR: $\delta=117.6,121.0,124.8,126.9,128.8,129.2,130.4,131.3,133.8,137.6,159.1,163.4$. EIMS $m / z$ : $341.20\left[\mathrm{M}+\mathrm{H}^{+}\right]:[\mathrm{M}-2 \mathrm{Cl}]^{+}=270.31 ;[\mathrm{M}-2 \mathrm{~F}]^{+}=303.32$. Anal.(\%) calcd for $\mathrm{C}_{16} \mathrm{H}_{8} \mathrm{Cl}_{2} \mathrm{~F}_{2} \mathrm{~S}, \mathrm{C} 56.32$; H 2.36, found C $56.38 ; \mathrm{H} 2.38$.

\subsubsection{2,5-Bis(3,5-dimethylphenyl) thiophene (3e)}

Greenish yellow solid, mp. $185^{\circ} \mathrm{C} ;{ }^{1} \mathrm{H}-\mathrm{NMR}: \delta=7.02$ (s, 2H-Thiophene), 7.54-7.47 (m, 6H-Ar), 3.29 (s, 12H-CH $)_{3} .{ }^{13} \mathrm{C}-\mathrm{NMR}: \delta=21.7\left(\mathrm{CH}_{3}\right.$ of aryl $), 127.8,128.8,131.1,133.8,138.2,138.6,139.1$. EIMS $m / z: 292.44\left[\mathrm{M}+\mathrm{H}^{+}\right]$; $[\mathrm{M}-4 \mathrm{Me}]^{+}=232.34$. Anal.(\%) calcd for $\mathrm{C}_{20} \mathrm{H}_{20} \mathrm{~S}, \mathrm{C} 82.14, \mathrm{H}$ 6.89, found C 82.18; H 6.80 .

\subsubsection{2,5-Bis(3,4-dichlorophenyl) thiophene (3f)}

Golden yellow solid, mp. $170{ }^{\circ} \mathrm{C} ;{ }^{1} \mathrm{H}-\mathrm{NMR}: \delta=7.15$ (s, 2H-Thiophene), 7.58-7.53 (m, 6H-Ar). ${ }^{13} \mathrm{C}-\mathrm{NMR}: \delta=126.9,128.3,129.1,130.4,132.9,133.6,138.2$. EIMS $m / z: 373.22\left[\mathrm{M}+\mathrm{H}^{+}\right]:[\mathrm{M}-4 \mathrm{Cl}]^{+}=232.33$; $[\mathrm{M}-2 \mathrm{Cl}]^{+}=303.22$. Anal.(\%) calcd for $\mathrm{C}_{16} \mathrm{H}_{8} \mathrm{Cl}_{4} \mathrm{~S}, \mathrm{C} 51.30, \mathrm{H}$ 2.18, found $\mathrm{C} 51.37 ; \mathrm{H} 2.16$.

\subsection{X-ray Diffraction Analysis}

Single crystals of both thiophenes $\mathbf{2} \mathbf{d}$ and $\mathbf{2} \mathbf{f}$ with appropriate sizes were chosen from available sample under microscope. Which were fixed on glass tip using glue, purchased from local market. The glass needle was supported by copper pin and magnetic base. This whole assembly was mounted on Agilent SuperNova (dual source) Agilent Technologies Diffractometer, equipped with graphite-monochromatic $\mathrm{Cu} / \mathrm{Mo} \mathrm{K} \alpha$ radiation for data collection. The data collection was accomplished using CrysAlisPro software [44], at $296 \mathrm{~K}$ under $\mathrm{Cu} \mathrm{K} \alpha$ radiation. The structures were solved using SHELXS-97 [45], and refined by full-matrix least-squares methods on $\mathrm{F}^{2}$ using SHELXL-97, 
in-built with X-Seed [46]. All non-hydrogen atoms were refined anisotropically by full-matrix least squares methods [45]. The figures were drawn using PLATON in-built with wingx.

There are only aromatic $(\mathrm{C}-\mathrm{H})$ hydrogen atoms, which were positioned geometrically and treated as riding atoms with $\mathrm{C}-\mathrm{H}=0.93 \AA$ and $\mathrm{Uiso}(\mathrm{H})=1.2 \mathrm{Ueq}(\mathrm{C})$ carbon atoms.

The CIFs for both molecules have been submitted to (The Cambridge Crystallographic Data Centre) CCDC and got CCDC numbers 1469610 and 1469611 for molecule $\mathbf{2 d}$ and $2 \mathrm{f}$ respectively. These CIFs can be ordered free of cost from CCDC 12 Union Road, Cambridge CB21 EZ, UK.

\subsection{Computational Methods}

Theoretical investigations were performed by using Gaussian 09 software [47]. Visualizations of graphics/geometries was achieved by using Gauss view 05 program [48]. Geometries of (2a-f) and (3a-f) were optimized by adopting hybrid B3LYP method without any symmetry constraints along with 6-31G $(\mathrm{d}, \mathrm{p})$ basis set at DFT level of theory [49,50]. Frontier molecular orbital analysis and molecular electrostatic potential mapping of both series $(\mathbf{2} \mathbf{a}-\mathbf{f})$ and $(\mathbf{3 a}-\mathbf{f})$ were simulated at same level of DFT as used for energy minima optimization.

\subsection{Antibacterial Assay}

The antibacterial assay of compounds $2 \mathbf{a}-3 \mathbf{f}$ was accomplished by method reported by of Nasrullah and co-workers [12]. Bacillus subtilis, Staphylococcus aureus were used as Gram-positive bacteria and Escherichia coli, Pseudomonas aeruginosa, Salmonella typhi, Shigelladysenteriae used as Gram-negative bacteria.

Solutions of the compounds were made by dissolving in a solvent of known concentration ( 5 and $10 \mu \mathrm{g} / \mathrm{mL}$ ). Samples of different concentrations were prepared by already known volumes of compounds. Ampicillin (positive control) was prepared by using the same methodology. By using only solvent negative control was prepared. At $137^{\circ} \mathrm{C}$ for $30 \mathrm{~min}$ glass apparatus was sterilized. In sterile glass Petri plates nutrient agar was added. In test tubes having nutrient broth, sub-cultures were injected and left at $37^{\circ} \mathrm{C}$ for $16 \mathrm{~h}$ on rotary shaker. On inoculated nutrient agar medium positive and negative controls, all discs and test samples were solidified at $37 \pm 2{ }^{\circ} \mathrm{C}$ for $24 \mathrm{~h}$. With the help of an ordinary ruler, microbial growth was measured.

\subsection{Nitric Oxide Scavenging Activity}

By following procedure reported by Garrat and co-workers [51] nitric oxide scavenging activity of all compounds was carried out.

\section{Conclusions}

In summary, we report the synthesis of various 2-aryl-5-chlorothiophenes and 2,5-biarylthiophenes, starting from 2-bromo-5-chloro thiophenes. In Suzuki coupling reactions, different boronic acids/esters react with 2-bromo-5-chloro thiophenes in the presence of a palladium catalyst. X-ray and calculated geometric parameters of $\mathbf{2 d}$ and $\mathbf{2 f}$, corroborate very nicely to each other. Reactive sites and electronic effect of group attached to benzene ring was investigated by ESP analysis. By noting the results of this study it is revealed that some of the synthesized compounds of 2-bromo-5-chloro thiophenes can be used as antibacterial agents.

Acknowledgments: The present data is the part of M.phil thesis research work of Quratulain. The authors also gratefully acknowledge the financial support by Higher education commission of pakistan (HEC Project No. 20-1465/R\&D/09/5458).

Author Contributions: Nasir Rasool, Tariq Mahmood and Khurshid Ayub conceived and designed the experiments; Aqsa Kanwal, Tehmina Rasheed and Quratulain Ain performed the experiments; Muhammad Nadeem Arshad, Muhammad Zubair and Khalid Mohammed Khan analyzed the data; Abdullah M. Asiri, Muhammad Zia-Ul-Haq and Hawa Z. E. Jaafar contributed reagents/materials/analysis tools; Nasir Rasool and Tehmina Rasheed wrote the paper. 
Conflicts of Interest: The authors declare no conflict of interest.

\section{References}

1. Parry, P.R.; Wang, C.; Batsanov, A.S.; Bryce, M.R.; Tarbit, B. Functionalized pyridylboronic acids and their Suzuki cross-coupling reactions to yield novel heteroarylpyridines. J. Org. Chem. 2002, 67, 7541-7543. [CrossRef] [PubMed]

2. Proutiere, F.; Aufiero, M.; Schoenebeck, F. Reactivity and stability of dinuclear Pd(I) complexes: Studies on the active catalytic species, insights into precatalyst activation and deactivation, and application in highly selective cross-coupling reactions. J. Am. Chem. Soc. 2011, 134, 606-612. [CrossRef] [PubMed]

3. Yin, L.; Liebscher, J. Carbon-carbon coupling reactions catalyzed by heterogeneous palladium catalysts. Chem. Rev. 2007, 107, 133-173. [CrossRef] [PubMed]

4. Joshaghani, M.; Daryanavard, M.; Rafiee, E.; Nadri, S. Synthesis and applications of a new palladacycle as a high active catalyst in the Suzuki couplings. J. Organomet. Chem. 2008, 693, 3135-3140. [CrossRef]

5. Mora, M.; Jiménez-Sanchidrián, C.; Ruiz, J.R. Suzuki cross-coupling reactions over Pd(II)-hydrotalcite catalysts in water. J. Mol. Catal. A Chem. 2008, 285, 79-83. [CrossRef]

6. Zim, D.; Nobre, S.M.; Monteiro, A.L. Suzuki cross-coupling reaction catalyzed by sulfur-containing palladacycles: Formation of palladium active species. J. Mol. Catal. A Chem. 2008, 287, 16-23. [CrossRef]

7. Guan, R.F.; Zhou, C.J.; Feng, S.Y.; Berg, D.J.; Stobart, S.R. The application of Suzuki coupling reaction on the preparation of carbosilane dendrimers with 4-(naphthalen-1-yl) phenyl core. Chin. Chem. Lett. 2006, 17, 293-295.

8. Abbas, S.; Hussain, M.; Ali, S.; Parvez, M.; Raza, A.; Haider, A.; Iqbal, J. Structural, enzyme inhibition, antibacterial and DNA protection studies of organotin(IV) derivatives of thiophene-2-carboxylic acid. J. Organomet. Chem. 2013, 724, 255-261. [CrossRef]

9. Gouda, M.A.; Berghot, M.A.; Baz, E.A.; Hamama, W.S. Synthesis, antitumor and antioxidant evaluation of some new thiazole and thiophene derivatives incorporated coumarin moiety. Med. Chem. Res. 2012, 21, 1062-1070. [CrossRef]

10. Rizwan, K.; Zubair, M.; Rasool, N.; Ali, S.; Zahoor, A.F.; Rana, U.A.; Khan, S.U.-D.; Shahid, M.; Zia-Ul-Haq, M.; Jaafar, H.Z. Regioselective synthesis of 2-(bromomethyl)-5-aryl-thiophene derivatives via palladium $(0)$ catalyzed suzuki cross-coupling reactions: As antithrombotic and haemolytically active molecules. Chem. Cent. J. 2014, 8. [CrossRef] [PubMed]

11. Gull, Y.; Rasool, N.; Noreen, M.; Nasim, F.-u.-H.; Yaqoob, A.; Kousar, S.; Rashid, U.; Bukhari, I.H.; Zubair, M.; Islam, M.S. Efficient synthesis of 2-amino-6-arylbenzothiazoles via $\mathrm{Pd}(0)$ Suzuki cross coupling reactions: Potent urease enzyme inhibition and nitric oxide scavenging activities of the products. Molecules 2013, 18, 8845-8857. [CrossRef] [PubMed]

12. Suzuki, A. Cross-coupling reactions of organoboranes: An easy way to construct $\mathrm{C}-\mathrm{C}$ bonds (Nobel Lecture). Angew. Chem. Int. Ed. 2011, 50, 6722-6737. [CrossRef] [PubMed]

13. Kotha, S.; Lahiri, K.; Kashinath, D. Recent applications of the Suzuki-Miyaura cross-coupling reaction in organic synthesis. Tetrahedron 2002, 58, 9633-9695. [CrossRef]

14. Alonso, F.; Beletskaya, I.P.; Yus, M. Non-conventional methodologies for transition-metal catalysed carbon-carbon coupling: A critical overview. Part 2: The Suzuki reaction. Tetrahedron 2008, 64, 3047-3101. [CrossRef]

15. Noreen, M.; Rasool, N.; Gull, Y.; Zahoor, A.F.; Yaqoob, A.; Kousar, S.; Zubair, M.; Bukhari, I.H.; Rana, U.A. A facile synthesis of new 5-aryl-thiophenes bearing sulfonamide moiety via $\operatorname{Pd}(0)$-catalyzed Suzuki-Miyaura cross coupling reactions and 5-bromothiophene-2-acetamide: As potent urease inhibitor, antibacterial agent and hemolytically active compounds. J. Saudi Chem. Soc. 2014, in press. [CrossRef]

16. Ali, S.; Rasool, N.; Ullah, A.; Nasim, F.-u.-H.; Yaqoob, A.; Zubair, M.; Rashid, U.; Riaz, M. Design and synthesis of arylthiophene-2-carbaldehydes via Suzuki-Miyaura reactions and their biological evaluation. Molecules 2013, 18, 14711-14725. [CrossRef] [PubMed]

17. Rasheed, T.; Rasool, N.; Noreen, M.; Gull, Y.; Zubair, M.; Ullah, A.; Rana, U.A. Palladium(0) catalyzed Suzuki cross-coupling reactions of 2,4-dibromothiophene: Selectivity, characterization and biological applications. J. Sulfur Chem. 2015, 36, 240-250. [CrossRef] 
18. Dong, C.-G.; Hu, Q.-S. Preferential oxidative addition in palladium(0)-catalyzed Suzuki cross-coupling reactions of dihaloarenes with arylboronic acids. J. Am. Chem. Soc. 2005, 127, 10006-10007. [CrossRef] [PubMed]

19. Campaigne, E.; Foye, W.O. The synthesis of 2,5-diarylthiophenes. J. Org. Chem. 1952, 17, $1405-1412$. [CrossRef]

20. Robbins, D.W.; Hartwig, J.F. A C-H borylation approach to Suzuki-Miyaura coupling of typically unstable 2-heteroaryl and polyfluorophenyl boronates. Org. Lett. 2012, 14, 4266-4269. [CrossRef] [PubMed]

21. Petersen, T.P.; Becker, M.R.; Knochel, P. Continuous flow magnesiation of functionalized heterocycles and acrylates with TMPMgCl.LiCl. Angew. Chem. Int. Ed. 2014, 53, 7933-7937. [CrossRef] [PubMed]

22. Luo, B.-T.; Liu, H.; Lin, Z.-J.; Jiang, J.; Shen, D.-S.; Liu, R.-Z.; Ke, Z.; Liu, F.-S. Aerobic and efficient direct arylation of five-membered heteroarenes and their benzocondensed derivatives with aryl bromides by bulky $\alpha$-hydroxyimine palladium complexes. Organometallics 2015, 34, 4881-4894. [CrossRef]

23. Noreen, M.; Rasool, N.; Gull, Y.; Zubair, M.; Mahmood, T.; Ayub, K.; Nasim, F.-U.-H.; Yaqoob, A.; Zia-Ul-Haq, M.; de Feo, V. Synthesis, density functional theory (DFT), urease inhibition and antimicrobial activities of 5-aryl thiophenes bearing sulphonylacetamide moieties. Molecules 2015, 20, 19914-19928. [CrossRef] [PubMed]

24. Rahman, T.U.; Arfan, M.; Mahmood, T.; Liaqat, W.; Gilani, M.A.; Uddin, G.; Ludwig, R.; Zaman, K.; Choudhary, M.I.; Khattak, K.F. Isolation, spectroscopic and density functional theory studies of 7-(4-methoxyphenyl)-9H-furo[2,3-f]chromen-9-one: A new flavonoid from the bark of Millettia ovalifolia. Spectrochim. Acta Part A Mol. Biomol. Spectrosc. 2015, 146, 24-32. [CrossRef] [PubMed]

25. Liégault, B.; Petrov, I.; Gorelsky, S.I.; Fagnou, K. Modulating reactivity and diverting selectivity in palladium-catalyzed heteroaromatic direct arylation through the use of a chloride activating/blocking group. J. Org. Chem. 2010, 75, 1047-1060. [CrossRef] [PubMed]

26. Yanagisawa, S.; Itami, K. Palladium $/ 2,2^{\prime}$-bipyridyl $/ \mathrm{Ag}_{2} \mathrm{CO}_{3}$ catalyst for $\mathrm{C}-\mathrm{H}$ bond arylation of heteroarenes with haloarenes. Tetrahedron 2011, 67, 4425-4430. [CrossRef]

27. René, O.; Fagnou, K. Room-temperature direct arylation of polyfluorinated arenes under biphasic conditions. Org. Lett. 2010, 12, 2116-2119. [CrossRef] [PubMed]

28. Bayh, O.; Awad, H.; Mongin, F.; Hoarau, C.; Bischoff, L.; Trécourt, F.; Quéguiner, G.; Marsais, F.; Blanco, F.; Abarca, B. Deprotonation of benzoxazole and oxazole using lithium magnesates. J. Org. Chem. 2005, 70, 5190-5196. [CrossRef] [PubMed]

29. Tùng, Đ.T.; Tuân, Đ.T.; Rasool, N.; Villinger, A.; Reinke, H.; Fischer, C.; Langer, P. Regioselective Palladium(0)catalyzed cross-coupling reactions and metal-halide exchange reactions of tetrabromothiophene: Optimization, scope and limitations. Adv. Synth. Catal. 2009, 351, 1595-1609. [CrossRef]

30. Bak, B.; Christensen, D.; Hansen-Nygaard, L.; Rastrup-Andersen, J. The structure of thiophene. J. Mol. Spectrosc. 1961, 7, 58-63. [CrossRef]

31. Ahmed, M.N.; Yasin, K.A.; Ayub, K.; Mahmood, T.; Tahir, M.N.; Khan, B.A.; Hafeez, M.; Ahmed, M. Click one pot synthesis, spectral analyses, crystal structures, DFT studies and brine shrimp cytotoxicity assay of two newly synthesized 1,4,5-trisubstituted 1,2,3-triazoles. J. Mol. Struct. 2016, 1106, 430-439. [CrossRef]

32. Arshad, M.N.; Mahmood, T.; Khan, A.F.; Zia-Ur-Rehman, M.; Asiri, A.M.; Khan, I.U.; Ayub, K.; Mukhtar, A.; Saeed, M.T. Synthesis, crystal structure and spectroscopic properties of 1,2-benzothiazine derivatives: An experimental and DFT study. Chin. J. Struct. Chem. 2015, 34, 15-25.

33. Arshad, M.N.; Asiri, A.M.; Alamry, K.A.; Mahmood, T.; Gilani, M.A.; Ayub, K.; Birinji, A.S. Synthesis, crystal structure, spectroscopic and density functional theory (DFT) study of N-[3-anthracen-9-yl-1(4-bromo-phenyl)-allylidene]-N-benzenesulfonohydrazine. Spectrochim. Acta Part A Mol. Biomol. Spectrosc. 2015, 142, 364-374. [CrossRef] [PubMed]

34. Honig, B.; Nicholls, A. Classical electrostatics in biology and chemistry. Science 1995, 268, 1144-1149. [CrossRef] [PubMed]

35. Politzer, P.; Murray, J.S. The fundamental nature and role of the electrostatic potential in atoms and molecules. Theor. Chem. Acc. 2002, 108, 134-142. [CrossRef]

36. Elsabee, M.Z.; Ali, E.A.; Mokhtar, S.M.; Eweis, M. Synthesis, characterization polymerization and antibacterial properties of novel thiophene substituted acrylamide. React. Funct. Polym. 2011, 71, 1187-1194. [CrossRef] 
37. Bondock, S.; Fadaly, W.; Metwally, M.A. Synthesis and antimicrobial activity of some new thiazole, thiophene and pyrazole derivatives containing benzothiazole moiety. Eur. J. Med. Chem. 2010, 45, 3692-3701. [CrossRef] [PubMed]

38. Refat, H.M.; Fadda, A. Synthesis and antimicrobial activity of some novel hydrazide, benzochromenone, dihydropyridine, pyrrole, thiazole and thiophene derivatives. Eur. J. Med. Chem. 2013, 70, 419-426. [CrossRef] [PubMed]

39. Mitra, I.; Saha, A.; Roy, K. Pharmacophore mapping of arylamino-substituted benzo[b]thiophenes as free radical scavengers. J. Mol. Model. 2010, 16, 1585-1596. [CrossRef] [PubMed]

40. Harinath, Y.; Reddy, D.H.K.; Kumar, B.N.; Apparao, C.; Seshaiah, K. Synthesis, spectral characterization and antioxidant activity studies of a bidentate Schiff base, 5-methyl thiophene-2-carboxaldehyde-carbohydrazone and its $\mathrm{Cd}(\mathrm{II}), \mathrm{Cu}(\mathrm{II}), \mathrm{Ni}(\mathrm{II})$ and $\mathrm{Zn}(\mathrm{II})$ complexes. Spectrochim. Acta Part A Mol. Biomol. Spectrosc. 2013, 101, 264-272. [CrossRef] [PubMed]

41. Meotti, F.C.; Silva, D.O.; dos Santos, A.R.; Zeni, G.; Rocha, J.B.T.; Nogueira, C.W. Thiophenes and furans derivatives: A new class of potential pharmacological agents. Environ. Toxicol. Pharmacol. 2003, 15, 37-44. [CrossRef] [PubMed]

42. Queiroz, M.-J.R.; Ferreira, I.C.; Calhelha, R.C.; Estevinho, L.M. Synthesis and antioxidant activity evaluation of new 7-aryl or 7-heteroarylamino-2,3-dimethylbenzo[b]thiophenes obtained by Buchwald-Hartwig C-N cross-coupling. Bioorg. Med. Chem. 2007, 15, 1788-1794. [CrossRef] [PubMed]

43. Fadda, A.A.; Berghot, M.A.; Amer, F.A.; Badawy, D.S.; Bayoumy, N.M. Synthesis and antioxidant and antitumor activity of novel pyridine, chromene, thiophene and thiazole derivatives. Arch. Pharm. 2012, 345, 378-385. [CrossRef] [PubMed]

44. CrysAlis ${ }^{\text {Pro }}$; Agilent Technologies: Oxfordshire, UK, 2012.

45. Sheldrick, G.M. A short history of SHELX. Acta Crystallogr. Sect. A Found. Crystallogr. 2007, 64, 112-122. [CrossRef] [PubMed]

46. Barbour, L.J. X-Seed-A software tool for supramolecular crystallography. J. Supramol. Chem. 2001, 1, 189-191. [CrossRef]

47. Frisch, M.; Trucks, G.; Schlegel, H.; Scuseria, G.; Robb, M.; Cheeseman, J.; Scalmani, G.; Barone, V.; Mennucci, B.; Petersson, G. Fox Gaussian 09, Revision C. 01; Gaussian Inc.: Wallingford, CT, USA, 2013.

48. Roy, D.; Todd, K.; John, M. Gauss View; Version 5; Semichem, Inc.: Shawnee Mission, KS, USA, 2009.

49. Becke, A.D. Density-functional exchange-energy approximation with correct asymptotic behavior. Phys. Rev. A 1988, 38, 3098-3100. [CrossRef]

50. Yanai, T.; Tew, D.P.; Handy, N.C. A new hybrid exchange-Correlation functional using the Coulomb-attenuating method (CAM-B3LYP). Chem. Phys. Lett. 2004, 393, 51-57. [CrossRef]

51. Garratt, D. Synthetic Organic Compounds. In The Quantitative Analysis of Drugs; Springer: New York, NY, USA, 1964; pp. 700-715. 